\title{
MARITAL STRESS - DISEASE AND DILEMMA
}

\author{
MAJOR J. R. BIRD, M.B., B.S., M.R.C.Psych., D.P.H., R.A.M.C.
}

Royal Victoria Hospital, Netley

SUMMARY: This paper surveys marital stress. It highlights difficulties in its
identification and diagnosis. The serviceman's marriage is conceptualised in such
a way as to raise questions regarding its treatment when under stress.

Introduction

Whoever it was who said "Marriages are made in Heaven", clearly envisaged a manufacturing area free of industrial strife. Unfortunately the shop floor of human relations deals somewhat less kindly with the product.

The Registrar General's Statistical Review (1972) provides chilling evidence of the loss making aspects of this 'heavenly product'. In 1965 there were 37,785 divorces in England and Wales. In 1972 divorces had trebled to 119,025 whilst 426,241 marriages were contracted. A fairly evident prediction that 1 in 4 marriages will end in divorce can be made but what is not noted is the number of remaining marriages under variable stress.

In pure terms of human misery Dicks (1967) phrased it best when he wrote, "the 3,350 per cent increase in divorce, is perhaps comparable to the ravages of an epidemic".

Clearly the service family will be exposed to the same marital risks as its civilian counterpart but in addition faces stresses peculiar to service life. Many authors since the war have identified factors stressful to service families but whilst marital disharmony was frequently mentioned, only two make particular and significant reference to its extent. McGhie and McConvell (1953) surveying service psychiatry in the Far East in 1957 noted that out of 82 wives seen, "domestic disharmony" was the presenting symptom in 26 cases, with headache the next most common symptom in 8 cases. Again Wawman (1973) assessing 50 consecutive wives seen in 1968 found serious marital discord, not obviously related to service stresses in 30 per cent of the cases. It was somewhat surprising then, to find Bernstein et al (1976) in a survey of a year's work in a family practice in Germany, not directly mentioning marital problems despite 1,214 psychiatric consultations. Yet he confirms the existence of marital stress when he notes, "the 10 deliberate overdoses, were all due to marital disharmony".

His difficulty at classifying marital stress was clearly shared by Glen (1972) who, surveying work in the psychiatric services of BMH Singapore in 1969-70 writes: "under the classification of 'nil' diagnosis 24 of the 70 males were disciplinary cases and 20 of the 38 females were classified as marital problems".

It may be as Herndon (1964) points out that there is a tendency to see such events as marital disorders, illegitimacy and divorce as social problems, "largely ignored by physicians, though clearly we face the medical complications of marital conflict". 
The Report of the Army Welfare Inquiry Committee (1976) takes great note of marital stress in service families, mentioning "complex cases of social distress requiring expert professional assistance". The Report highlights the fact that, though the Army strength has fallen by 3.8 per cent between 1969-1974, the number of families rose by 5.4 per cent and in BAOR at present there are approximately 30,000 wives. An 'at risk' population?

Further evidence on the extent of marital stress is provided by Woodruffe (1977) who mentions 613 cases of significant matrimonial problems managed by SSAFA Social Workers in BAOR during 1976, and Hutchins (1977) reviewing his own general practice estimated that one in four wives seen had matrimonial problems.

\section{Collusion and scapegoating - the sacrificial goat syndrome}

What seemed clear in the writings on the various stresses affecting the serviceman's family, was that the emphasis seemed to be on illness and distress in the wives and children. A parallel effect on the serviceman's morale and motivation was consistently and rightly stressed. What appears not to have been highlighted, are the peculiar stresses acting on the 'two person relationship', the marriage. Marital Disorder and Domestic Disharmony curiously then come over as psychopathology belonging to the wife and not shared with her husband.

If this is so, then a two person relationship disorder with manifest and direrse symptomatology is being treated as an illness of one person, the wife or indeed a child.

Several writers have stressed how one family member is made to hold the illness present in the family. Muir (1975) saw this scapegoated member as serving a homeostatic, balancing function in the family. Whilst Frances and Gale (1973), writing on family structure and treatment in the military, noted how rarely the unhappy, stressed wife voiced overt displeasure at her husband, presenting usually with physical or neurotic symptoms, or by acting out behaviour.

The presentation of a child, with the invitation to make its 'sick behaviour' the focus of attention, is frequently noted in Child Guidance Clinic Work and Dickerson and Arthur (1965) surveying their work with children of American Navy families noted, "marital disharmony was prominent".

Undoubtedly it was the writer's experience whilst working as a child psychiatrist, that marital problems were frequently revealed when the invited point of involvement was the youngster. That such a finding was often a relief for the parents was also noteworthy, confiming Kanner's (1972) contention that the child is frequently "the admission ticket for the family".

It may be that there exists a shared unconscious collusiveness. Within the family the scapegoated child contains the tension felt as unbearable by the parents, whilst collusion between husband and wife presents one partner alone as sick and requiring attention. The wife frequently fills the role, undergoes repeated physical tests, receives treatment but remains 'ill': As Richter (1974) observes, "often a physically ill person cannot recover as long as his family life is seriously upset". None the less, the difficulty remains, to identify the cause behind the symptoms. Frequently the marriage is stated to be entirely happy, 
suspicions are lulled and multiple investigations and approaches directed elsewhere. That collusion provides some gain great enough for the partner to be and remain sick is shrewdly mentioned by Symonds (1973) who sees some wives regarding marriage as their "declaration of dependence". He goes on to say such wives deny marital unhappiness but are constantly developing psychosomatic and neurotic symptoms and "if for any reason these are questioned or the marriage does not seem to be all they expected, they are in a panic and cling even more. Their rage at being frustrated is immediately suppressed and cannot be acknowledged since it seems so destructive".

Finally collusion can exist interwoven into the fabric of the doctor-patientunit network, to ignore the extent and severity of marital disturbance, frequently until repair is too late. It may be that a difficulty for the physician is in moving away from the familiar bipolar relationship of doctor-patient to face the tensions of a three person therapy. The unit too, as the Army Welfare Inquiry Committee (1976) notes, "may in seeking to solve problems quickly, too often deal with the symptoms and not the causes of personal and family problems".

And after the sacrifice?

The writer, to elicit evidence of actual marital stress presenting finally in psychiatric service, made a retrospective survey of 122 married patients seen by him consecutively at the British Military Hospital, Hannover during 1975. Marital stress existed in 60 cases (49 per cent) but was presented directly in only 3 cases; i.e. couples seeking marital treatment (Table I). Complete marital breakdown invariably presenting as some other disorder was noted in 9 cases. Of the remaining 48 cases, marital stress was mentioned directly in 26 cases but usually after other symptoms had been 'offered' first. In 22 cases marital stress was rapidly uncovered in the first interview, but not initially mentioned by the patient. A consistent belief patients expressed was that the medical services would not be interested, unable or unwilling to help with marital problems.

Table I

Survey of 60 married patients with marital stress

\begin{tabular}{|c|c|c|}
\hline Patient presenting & Wife-39 & Husband-18 \\
\hline Duration of marriage & $\begin{array}{l}\text { Under } 5 \text { years } \\
(7 \text { cases under } 1 \text { year } \\
5 \text { to } 10 \text { years }\end{array}$ & $\begin{array}{l}-25 \text { cases } 10 \text { to } 15 \text { years }-7 \text { cases } \\
-21 \text { cases over } 15 \text { years }-7 \text { cases }\end{array}$ \\
\hline Age of patient & $\begin{array}{l}\text { Under } 20 \text { years } \\
20 \text { to } 25 \text { years } \\
26 \text { to } 30 \text { years }\end{array}$ & $\begin{array}{l}\text { - } 1 \text { case } 30-35 \text { years }-12 \text { cases } \\
-22 \text { cases } 36-40 \text { years }-6 \text { cases } \\
-16 \text { cases over } 40 \text { years }-6 \text { cases }\end{array}$ \\
\hline Rank of husband & $\begin{array}{l}\text { Private or equivalen } \\
\text { Junior N.C.O. }\end{array}$ & $\begin{array}{l}t-17 \text { cases Senior N.C.O. }-13 \text { cases } \\
-24 \text { cases Officers }-6 \text { cases }\end{array}$ \\
\hline
\end{tabular}

Some special features and presenting symptoms of the marital stress revealed at interview, have been highlighted (Table II). 
Table II

Special features and symptoms of stress in 60 married patients

\begin{tabular}{|c|c|c|}
\hline Special features & $\begin{array}{l}\text { Couple of different nationalities } \\
\text { Disturbed family background } \\
\text { One parent died before patient was } 15 \text { years ol }\end{array}$ & $\begin{array}{l}\text { - } 9 \text { cases } \\
-19 \text { cases } \\
-13 \text { cases }\end{array}$ \\
\hline \multirow[t]{2}{*}{ Symptoms of stress } & $\begin{array}{r}\text { Actual physical violence- }- \text { Husband to wife } \\
\text { Wife to child } \\
\text { Wife to husband }\end{array}$ & $\begin{array}{l}-26 \text { cases } \\
-7 \text { and } \\
4 \text { cases }\end{array}$ \\
\hline & $\begin{array}{l}\text { Sexual problems } \\
\text { Role problems } \\
\text { Separation difficulties } \\
\text { presenting as overdose } \\
\text { Excess drinking } \\
\text { Poor communication } \\
\text { (directly stated) } \\
\text { Infidelity }\end{array}$ & $\begin{array}{l}\text { - } 22 \text { cases } \\
-20 \text { cases } \\
-19 \text { cases } \\
-17 \text { cases } \\
-11 \text { cases } \\
-10 \text { cases } \\
-8 \text { cases }\end{array}$ \\
\hline
\end{tabular}

The fact that 9 couples were of different nationality and culture at marriage obviously reflected the serviceman's mobility. Difficulties in marital adjustment have been stressed by Dicks (1967) and Wallis (1968). The early loss of a parent leading to later difficulties in maintaining a marital and parental role, has been noted by Britton (1969) and Gay and Tonge (1967) who, writing on the late effects of loss of parent in childhood found an increased incidence of psychogenic disorder and marital disharmony.

\section{Violence}

The problem of marital violence is not unique to service life, though 30 cases (50 per cent) seemed high. However, Levinger (1966) reports physical abuse in 368 of 600 couples (61 per cent) seeking divorce and Gelles (1972) suggests violence occurs in 50 per cent of stressed marriages. Saunders (1977) with figure of 15.6 per cent from 1,600 couples seeking help, suggests much marital, violence is hidden.

Whilst violence was rarely the solitary complaint, being associated frequently with excess drinking and sexual difficulties, the pattern of response to violence was interesting. Those who complained most bitterly were usually wives in the younger age group, married at a young age and exposed to violence from the early days of marriage, a point noted by Borland (1976). Amongst older wives, violence seemed often mentioned only in association with other areas of neglect and it was felt that there existed some subtle interplay of masochism with reinforcement of aggression by 'giving in', a concept discussed by Beck and Jones (1973).

It was clear that intense frustration, unwillingness to tolerate even acceptable postponement of gratification was often in evidence, with rage frequently 
a prelude to violence in the men and acting out behaviour by the women. As Mace (1976) has observed, there seemed to be in these stressed marriages an incapacity of couples to cope with their own or each other's anger. The traditionally viewed 'cry for help' of the overdose was heard, perhaps cynically, as a 'bellow of rage' in very many cases.

\section{Separation difficulties}

The problems of separation in service life have received much attention from amongst others, Isay (1968), Wawman (1973) and Frances and Gale (1973) who highlighted the anxiety as being a shared fantasy of abandonment. It was less the separation than the husband's return that led to difficulties. Often a stressed marriage was somehow expected to improve following separation, as though sexual health and performance would be revitalised ignoring and denying underlying disturbing causes already in existence.

What seemed to happen was that couples were not able to cope with frequent upheavals, the husband's 'coming and going'. This was seen also by Pearlman (1970) who reviewed separation anxiety in naval wives in the United States and said, "it seemed that repeated separation had prevented wives from learning how to deal maturely with their husbands". Frequent absence and return is an inescapable feature of service life demonstrably so with Ulster tours and it may well be we are seeing the progressive effects on marriages, as Rosenfeld and Rosenstein (1973) observed, of such cumulative disruption.

In addition to separation, moves are a constant source of stress. The effects of these on family life have been covered by various authors, including McAllister et al (1973); Barrett and Noble (1973) and McKain (1973) who wrote specifically on relocation in the military. Such moves, frequently crossing cultural boundaries and leading to sub-culture, indeed enclave life, are felt to be fundamental in the development of much marital stress. The young wife is unable to establish with any permanency her role as a homemaker, indeed a Married Quarter is not her home. There is rarely a sense of shared purpose in saving for furniture or luxury items and planning decorations. The husband cannot be seen as head of a household held in trust from the 'housing commandant'. This situation must inevitably reduce creativity and personal effort. The wife, in frustration, questions her husband's power and potency and these increasing doubts as Kolb and Straus (1974) noted lead to testing behaviour. The testing is a measure of intense insecurity and helplessness, frequently poorly verbalised and leading all too often to acting out as an escape from intensive inner conflict.

\section{Struggle for identity-family within family}

A striking feature in many stressed marriages, though by no means confined to these, was the readiness, indeed anxiety, to blame the services for every and all ills. This tendency to seek out and identify a 'bad object' at which dissatisfactions could be projected, caused the writer to conceptualise the service marriage as developing and functioning in a unique setting. Namely that service life is experienced as a further 'parental marriage'. The military authorities become parental figures for the soldier and In-Laws for a new wife. The soldier and 
his family must thus establish their identities within this 'projected' family. Development then may be seen along a continuum from 'birth' at entry into the services to 'adulthood' at the time of retirement.

The idea of the services as representing a family is widely held and valued. Within units, family aspects are encouraged and developed by the traditional paternalistic role of the Commanding Officer, visits from officers' wives, and the provision, like parents, of the material essentials of life. The parental imagery of the services is rapidly established and maintained, throughout and indeed beyond service engagements. Reunions and so forth take on the character of family anniversaries, religiously kept and widely enjoyed. The service marriage cannot then be seen as having a purely dyadic two person boundary but as having to structure and restructure itself in response to the pressure of its existence within the military family. Unlike its civilian counterpart, the service marriage is expected to toe a communal family line and there is little space for nonconformity.

That marital complaints in the services so rarely mention in-law or nuclear relative problems, can be seen as partly due to distance, but also through transference distortion. The services become the non-gratifying or punitive parents with husband and wife, themselves locked in childlike conflict, united to hurl abuse and defiance at 'them'. The couple can be perceived as experiencing and expressing aggressiveness and frustration that often has less to do with external situations than relationship difficulties. These may be the "loving and hating impulses" well described by Hughes (1974) now directed towards the "military parents' as the child responds with similar ambivalence towards its natural parents. The urge to attack the depriving object, felt to be the services, is experienced as futile and turned inwards leads to aggression or despair within the marriage. That such is often not the case, the 'military parents' seeking more to help by placing emphasis on man-management, family ties and dependency is indeed the irony.

Marrying younger and moving from one family the wife needs to adjust not to a separate existence but to a new role in a more complex family. Whatever her previous experience and status there follows an inevitable shift to become now identified with the social level and class of her husband, a point developed by Hart (1976). The changing role demands a capacity for sharing her husband which, as Heilbrunn (1967) noted, requires a particular maturity.

The husband as a soldier has specific duties. He must however seek to satisfy frequently conflicting demands, those of his 'military parents' and those of his wife. Marital stress emerging is not surprising. Direct aggression or criticism of parents is punished. The child may not rebel, but neither may he appear weak.

The inter-sibling struggle with his colleagues and peer group requires him to present a front which does not always reflect his inner tension and turmoil. To cope with this split the husband may seek to be the totally correct, 'perfect soldier' adopting such rigidity that shift at home is difficult. A factor often common, as L'Abate (1975) observes in marital conflict, is the husband's failure 
to bring hurt feelings into the home or to identify correctly an internal insecurity, devalues his wife's capacity to care and cope.

There has been a significant change in the roles of couples in modern marriage, well demonstrated by Ryder and Silver (1970). Such changes likened to the teenager struggling for identity with differing values from the parents, lead to further stress experienced internally and projected externally, against the restraining forces of the 'military parents'. The wish for gratification intensifies and within the marital setting may be manifested by complaints of sexual difficulty. No longer is the right to orgasm the prerogative of the male. The expectation, frequently demanded, for sexual satisfaction is noted by Nye (1974) and Salzman (1967) who sees the woman no longer as a silent partner, but as a participant, "expecting a share of the returns, as she makes abundantly clear".

It is questionable that her emancipation in the military family is yet so evident. Her struggles with the parental figures are symbolically evident in her demands upon and aggressive challenging of, the parental representatives, SSAFA Sisters, Social Workers, Padres, Doctors and Families Officer, and so forth. These are hard to see as a striving for independence, presenting more as adolescent rebellion, but is that so different?

If my concept has validity, then potential stress would exist beyond the infant marriage, the new baby in the military family, indeed until retirement from the services (A situation analogous to the adult leaving home). The survey of marital stress revealed four cases of significant discord directly related to retirement issues. Marital problems or problems of identity at the time of retirement from the services, have been confirmed by the work of others, namely McNeil and Giffen (1967); Wawman (1973) and Milowe (1964) who stressed the role confusion which can develop where the husband loses his defined service identity and his wife now takes on, perhaps for the first time, a real identity, no longer 'wife of' but separate from the military.

\section{Conclusion}

Marital stress cannot be ignored. In addjtion to effects, medical and social, on a couple and their children the services lose trained men, a point amply shown by O'Connor (1968) writing on servicemen leaving because of domestic and marital problems. Further, service marriages are not maintained within the relative anonymity of civilian life. Their development is inextricably linked with the military and the repercussions of marital stress are inevitably felt within the service community.

This paper has highlighted significant difficulties in the diagnosis of marital discord, not least because of patient attitudes but also our own. The very nature of the problem, its symptom abundance, inevitable complexity and emotive content produces a shared fantasy of despair. Fantasy because a worthwhile therapeutic approach can be possible given motivation on one side and willingness on the other. How treatment of these troubled marriages can usefully be undertaken is not within the scope of this paper but that such is necessary seems unarguable. Perhaps the need now is to review our 'after sales' service? 


\section{REFERENCES}

Barrett, C. L. and Noble, H. (1973). J. Marr. Fam. 2, 181

BECK, D. and JONES, M A. (1973). Progress on Family Problems. Family Service Association of America. New York

Bernstein, S., Jeffries, J. D.. and Pollock, A. A. (1976). J. roy Army med. Cps- 122, 193

BORLAND, M. (1976). Violence in the Family. Manchester University Press.

Britton, R. S. (1969). J. Child Psychol. 10, 245

Dickerson, W. and Arthur, R. (1965). Milit. Med. 130, 894

Dicks, H. V. (1967). Marital Tensions. Routledge \& Kegan Paul. London

Frances, A. and Gale, L. (1973). Fam. Proc. 12, 171

GAY, M. J. and Tonge, W. L. (1967). Brit. J. Psychiat. 113, 753

Gelles, R. J. (1972). The Violent Home. Sage Publications. London

Glen, D. W. F. (1972). J. roy. Army med Cps. 118, 135

Hart, N. (1976). When Marriage Ends. Tavistock Publications, London.

Heilbrunn, G. (1967). Amer. J. Psychother. 21, 750

Herndon, C. N. (1964). Foreword to: Marriage Counselling in Medical Practice. Ed. Nash, E. M., Jessner, L. and Abse, D. W. University of North Carolina Press, Chapel Hill.

Hughes, A. (1974): Psychotherapy Today. Ed. V. Varma. Constable, London

Hutchins, A. K. (1977). (Personal communication)

Isay, H. A. (1968). Psychiat. Quart. 42, 647

Kanner, L. (1972). Child Psychiatry, Charles C. Thomas. Illinois

Kolb, T. and Strauss, M. A. (1974). J. Marr. Fam. 36, 764

L'ABATE, D. (1975). J. Marr. Fam. Couns, 1, 69

LeVINGE, G, G. (1966). Amer. J. Orthopsychiat. 36, 803

MACE, D. R. (1976). J. Marr. Fam. Couns. 2, 131

McAllister, R., Butcher, E. W. and Kaiser, E. J. (1973). J. Marr. Fam. 2, 197

McGhre, J. F. and McConvell, D. J. (1953). J. roy. Army med Cps 99, 228

MCKaIN, J. L. (1973) J. Marr. Fam. 2, 197

McNeild, J. S. and Giffin, M. B. (1967). Amer J. Psychiat. 123, 848

Milowe, I. D. (1964). Ment. Hyg. (N.Y.) 48, 101

Muir, R. (1975). Brit. J. med. Psychol. 48, 267

NYE, F. Ivan (1974). J. Marr. Fam. 36, 240

O'Connor, P. J. (1968). Proc. roy. Soc. Med. 61, 973

Pearlman, C. A. (1970). Amer. J. Psychiat. 126, 946

Report of The Army Welfare Inquiry Committee (1976). Chairman: Professor J. C. Spencer, H.M.S.O. London.

Richter, H. E. (1974). The Family as Patient. Souvenir Press, London

Rosenfeld, J. M. and Rosenstein, E. (1973). J. Marr. Fam. 1, 131

Ryder, J. and Silver, H. (1970). Modern English Society. Methuen \& Co. London

Salzman, L. (1967). Arch. gen Psychiat. 17, 185

Saunders, D. G. (1977). J. Marr. Fam Couns. 3, 43

Symons, A. (1973). Psychoanalysis and Women. Ed. J. Miller, Penguin Books, U.S.A.

Wallis, G. G. (1968) Proc. roy. Soc. Med. 61, 976

Wawman, R. J. (1973). J. roy, Army med. Cps. 119, 14

WoodrufFe, A. (1977). Senior SSAFA Social Worker (Personal communication) 